\title{
Profile of Maxillofacial Fracture Patients at General Hospital in Surabaya
}

\author{
Bonfilio Neltio Ariobimo $^{(\mathbb{D})}$, Marjono Dwi Wibowo ${ }^{2 *(\mathbb{D})}$ Abdurachman $^{3(\mathbb{D}}$ \\ ${ }^{1}$ Faculty of Medicine, Universitas Airlangga, Surabaya, Indonesia \\ ${ }^{2}$ Department of Surgery Faculty of Medicine, Universitas Airlangga, Surabaya, Indonesia - Dr. Soetomo General Academic \\ Hospital Surabaya, Indonesia \\ ${ }^{3}$ Department of Anatomy and Histology, Faculty of Medicine, Universitas Airlangga, Surabaya, Indonesia
}

\section{A R T I C L E I N F O}

\section{Article history:}

Received 07 May 2021

Received in revised form 10 June 2019

Accepted 06 June 2021

Available online 30 June 2021

\section{Keywords:}

Maxillofacial fracture,

Trauma,

Traffic accident,

Mandibular.

*) Corresponding author: maryonodwi@gmail.com

\begin{abstract}
A B S T R A C T
Introduction: Maxillofacial fractures can be caused by blunt trauma or sharp trauma. The purpose of this study was to identify the characteristics in patients with maxillofacial fractures who were treated in the Head and Neck Surgery Division of Dr. Soetomo General Academic Hospital, Surabaya during 2016.

Methods: The research design was cross-sectional from patients with maxillofacial fractures. Those variables were evaluated are gender, age, type of etiology, site of maxillofacial fracture, gender and type of etiology based incidence, age and type of etiology based incidence. Data presented descriptively.

Results: From 68 patients, consisted of $57(83.82 \%)$ male, average age of 30.1 years old. The most common type of etiology was traffic accidents $(92.64 \%)$, most common site of fractures were mandibular $(33.33 \%)$, gender associated with the type of etiology was men who experienced traffic accidents $(79.41 \%)$, and the age associated with the most types of events was ages 26-45 years with traffic accidents $(47.05 \%)$.

Conclusion: Maxillofacial fractures still become the problem that mainly cause is traffic accidents which occurred mostly in male and mandibular fracture as the most common site of fracture.
\end{abstract}

\section{Introduction}

Face is one of the most important structures in the human body because it has many important functions and as a marker of aesthetic and social values, due to this trauma to the maxillofacial need special attention. Fractures in the bones forming face often causing patients to get immediate action in the emergency department. Maxillofacial fractures can be caused by blunt trauma or sharp trauma. There are several types of traumas that could cause injury to the maxillofacial area: traffic accidents, sports accidents, and violence as the most common causes of trauma in adolescents. ${ }^{1} 3.4 \%$ of fractures in skull / face are caused by severe and moderate trauma. ${ }^{2}$

Maxillofacial fractures could give an impact on patient's social, economic, and psychological. ${ }^{3}$ This is understandable because of the large amount of costs needed to handle the case and the possible disability that can arise from the presence of maxillofacial fractures.

Attempts to prevent maxillofacial fractures need to be addressed because the maxillofacial injury rate can be reduced by $25 \%$ if a preventive step is taken in the form of individual education regarding driving safety, safety guidelines before buying a vehicles, strict laws regarding mandatory use of helmets, seat belts, and ban on driving while drunk or sleepy. ${ }^{4}$ Characteristic profile of maxillofacial fracture patients in the Head and Neck Surgery regarding gender, age, etiology, and site of maxillofacial fractures is still lack of data. Based on this, researcher performed a study by evaluating medical records of patients with maxillofacial fractures to get reference material in carrying out preventive efforts in the form of education or counseling in order to reduce the incidence of facial trauma injuries that will lead to maxillofacial fractures and the consequences or complications that could occur.

\section{Methods}

This was a cross-sectional study conducted from May 2017 to December 2018. The subject used was all patients with maxillofacial fractures who were treated in the Head and Neck Surgery Division of Dr. Soetomo General Academic Hospital, Surabaya during January $1^{\text {st }}$ until Desember $31^{\text {st }} 2016$ with inclusion criteria that the subjects were patients who came to Dr. Soetomo General Academic Hospital and were handled by the Division of Head \& Neck Surgery with a diagnosis of maxillofacial fractures and had complete medical record data in accordance with 
the variables studied. We collected data regarding gender, age, type of etiology, and site of maxillofacial fracture from medical record. All data were analyzed in tabulation and presented descriptively.

\section{Results}

From 68 maxillofacial fracture patients who were treated in Head and Neck Surgery Division of Dr. Soetomo General Hospital, Surabaya during 2016, 57 (83.82\%) patients were men which suspected that men work outside more than women, while women usually spend more times at home and only a proportion of women could drive vehicles these reasons increase the ratio of men and women. The highest incidence of maxillofacial fractures occurred in patients age ranged from 26-45 years old and correspond with other studies which can be concluded that age of the second and third decades were the most vulnerable to maxillofacial fractures. The most common type of etiology which lead to maxillofacial fracture was traffic accidents in 63 subjects (92.64\%). Noted 114 fractures in maxillofacial bones and the most common site was in mandibular bone $(33.33 \%)$ as it was a prominent anatomy, and weak structure that easily affected with trauma (Table 1).

Table 1. Subjects characteristics

\begin{tabular}{|c|c|}
\hline Variable & $\mathrm{n}=68(100 \%)$ \\
\hline \multicolumn{2}{|l|}{ Gender } \\
\hline Male & $57(83.82 \%)$ \\
\hline Female & $11(16.17 \%)$ \\
\hline \multicolumn{2}{|l|}{ Age } \\
\hline $0-11$ & $0(0 \%)$ \\
\hline $12-25$ & $26(38.23 \%)$ \\
\hline $26-45$ & $33(48.52 \%)$ \\
\hline$>45$ & $9(13.23 \%)$ \\
\hline \multicolumn{2}{|l|}{ Type of etiology } \\
\hline Traffic accident & $63(92.64 \%)$ \\
\hline Occupational accident & $1(1.47 \%)$ \\
\hline Sport accident & $0(0 \%)$ \\
\hline Violence & $1(1.47 \%)$ \\
\hline Fall & $3(4.41 \%)$ \\
\hline \multicolumn{2}{|l|}{ Site of maxillofacial fracture } \\
\hline \multicolumn{2}{|l|}{ Upper face } \\
\hline Frontalis & $3(2.63 \%)$ \\
\hline \multicolumn{2}{|l|}{ Midface } \\
\hline Le Fort I & $2(1.75 \%)$ \\
\hline Le Fort II & $14(12.28 \%)$ \\
\hline Le Fort III & $4(3.50 \%)$ \\
\hline Blowout fracture & $1(0.87 \%)$ \\
\hline Zygomaticomaxillary Complex & $3(2.63 \%)$ \\
\hline Naso Orbito Ethmoidalis & $1(0.87 \%)$ \\
\hline Rima Orbita Inferior & $6(5.26 \%)$ \\
\hline
\end{tabular}

\begin{tabular}{lc}
\hline Isolated Maxilla & $15(13.15 \%)$ \\
\hline Isolated Zygoma & $17(14.91 \%)$ \\
\hline Nasal & $7(6.14 \%)$ \\
\hline Palatum & $1(0.87 \%)$ \\
\hline Lower face & $38(33.33 \%)$ \\
\hline Mandibular & \\
\hline Panfacial & $2(1.75 \%)$ \\
\hline Panfacial &
\end{tabular}

Men with traffic accident was the most common group of the relation between age and type of etiology, namely 54 patients $(79.41 \%)$ as male usually became the breadwinner of the family that they tend to stay outside longer which making them more at risk of trauma (Table 2).

Table 2. Gender and type of etiology based incidence

\begin{tabular}{lccc}
\hline Type of etiology & \multicolumn{2}{c}{ Gender } & \\
\cline { 2 - 3 } & Male & Female & Total \\
\hline Traffic accident & $54(79.41 \%)$ & $9(13.23 \%)$ & 63 \\
\hline $\begin{array}{l}\text { Non traffic } \\
\text { accident }\end{array}$ & $3(4.41 \%)$ & $2(2.94 \%)$ & 5 \\
\hline & 57 & 11 & 68 \\
\hline
\end{tabular}

Ages of 26-45 years with traffic accident was the most common group of the relation between age and type of etiology, namely 32 patients $(47.05 \%)$ as in those ages were productive age that spend more time on the outside especially with vehicles and have more chances to got trauma. (Table 3).

Table 3. Age and type of etiology-based incidence

\begin{tabular}{lccccc}
\hline $\begin{array}{l}\text { Type of } \\
\text { etiology }\end{array}$ & & & & & \\
\cline { 1 - 5 } $\begin{array}{l}\text { Traffic } \\
\text { accident }\end{array}$ & $0-11$ & $12-25$ & $26-45$ & $>45$ & \multirow{2}{*}{ Total } \\
\hline $\begin{array}{l}\text { Non- } \\
\text { traffic }\end{array}$ & 0 & 23 & 32 & 8 & 63 \\
\hline Accident & 0 & 3 & 1 & 1 & 5 \\
& $(0 \%)$ & $(43.81 \%)$ & $(1.47 \%)$ & $(1.47 \%)$ & \\
\hline \multicolumn{7}{c}{0} & 26 & 33 & 9 & 68 \\
\hline Discussion & & & & & \\
\hline
\end{tabular}

This study showed that traffic accidents were the most common cause of maxillofacial fractures and these results can be compared with other studies. ${ }^{5,6}$ In contrary, another study stated that violence is the most common cause. ${ }^{7}$ It has been shown from previous studies that in developing countries the most common cause of maxillofacial fractures was traffic accidents, whereas it was violence in developed countries. The lack traffic regulations accompanied by poor road infrastructure and old vehicles that do not have safety standards affect the incidence of trauma to the maxillofacial in developing countries. ${ }^{8}$ The incidence of traffic accidents 
can be related to an increase in vehicle density, an increase in urbanized population, inadequate infrastructure such as roads, road planning, using second hand vehicles, underage illegal motorists, driving under the influence of alcohol, and ignoring the rules of wearing seat belts and helmets. ${ }^{9}$ Prevention measures such as requiring the use of helmets, seat belts, promoting legal policies towards driving while drunken, counseling to always be vigilant in driving, and an explanation of adequate safety guidelines before buying a vehicle have shown a decrease in the incidence of traffic accidents. ${ }^{10}$ Banning on cell phone use while driving also reduces the incidence of traffic accidents. ${ }^{11}$

Individuals in the second and third decades of life represent the most productive stage period and have much energy to do more activities outside that could likely lead in increasing probability rate to trauma related maxillofacial fractures. ${ }^{5}$ This age group is referred to as aggressors and is often involved in dangerous activities such as sports and alcohol use, ${ }^{12}$ causing more potential to exceed the speed limit and be involved in a fight because it has a lot of physical energy. ${ }^{3}$ The possibility of driving a vehicle at high speed and less alert is more common is more common. ${ }^{13}$

Men patients dominantly occured in maxillofacial fractures in this study with ratio of 5.1: 1, similar result found in different study. ${ }^{14}$ Men usually became the breadwinner of the family that they tend to stay outside longer which making them more at risk of trauma, while women are more often in the house that they are limited by risk factors for trauma. ${ }^{15}$ Men work outside more than women, while women usually spend more times at home and only a proportion of women could drive vehicles these reasons increase the ratio of men and women to the incidence of maxillofacial fractures. ${ }^{9}$ The ratio of men and women in developing countries is lower than in developed countries because of the more activity of women outside the home to support economic and social status. ${ }^{16}$ In addition, men are more often involved in events that are risk factors for maxillofacial trauma, including traffic accidents, violence, sports, etc. ${ }^{17,18}$

The mandible is the most common site in this study which hypothesize that mandibular has prominent anatomy, as the only bone that can move, and its weak structure made it more often to be fractured when experiencing trauma. ${ }^{19}$ These results were agreed with other studies of maxillofacial fractures. ${ }^{3,10}$ Compared with studies of maxillofacial fractures in Iranian countries concluded that mandibular fractures as the most common site incidence as much as $47.1 \%$ of 384 occurrences of maxillofacial fractures. ${ }^{3}$ In addition, a study in India found $73.5 \%$ of 128 maxillofacial fracture events were mandibular fractures. ${ }^{19}$ Patients in trauma will tend to avoid collisions of their head, and the mandible will be the affected part of the impact. ${ }^{11}$

Maxillofacial fractures could also lead to concomitant trauma which causing much more complication such as head injury, extremity, and cervical vertebrae occur in some patients mostly due to high-speed traffic accident trauma. ${ }^{20}$ The incidence of head injury can be attributed to the impact of energy transfer when trauma occurs. In traffic accidents this impact will get worse if the individu does not use any safety equipment such as helmets and seat belts. ${ }^{21}$ This study limitation was some medical records are not completed in case of data such as etiology of traffic accident.

\section{Conclusion}

Maxillofacial fractures still become the problem that mainly happen due to trauma because of traffic accidents. From this study it is necessary to encourage more about safety driving counseling such as using especially for people in 26-45 years old. For medical personnel, knowledge and skills are needed in handling maxillofacial fractures, especially in mandibular fractures that often occured in the event of a trauma.

\section{Acknowledgement}

We would like to express our gratitude to dr. Urip Murtedjo, consultant of head and neck surgery as examiner who has helped directing and perfecting for completion research.

\section{Conflict of Interest}

The author stated that there is no conflict of interest.

\section{References}

1. Montovani JC, de Campos LMP, Gomes MA, et al. Etiology and incidence facial fractures in children and adults. Braz $\mathrm{J}$ Otorhinolaryngol 2006; 72: 235-241.

2. Amin, S., S. J. Achenbach, E. J. Atkinson, S. Khosla LJM. Trends in Fracture Incidence: A Population-Based Study Over 20 Years. J Bone Min Res 2015; 29: 581-589.

3. Samieirad S, Tohidi E, Shahidi-Payam A, et al. Retrospective study maxillofacial fractures epidemiology and treatment plans in Southeast of Iran. Med Oral Patol Oral y Cir Bucal 2015; 20: e729-e736.

4. Shankar V, LNU A. Prevalence of Maxillofacial Fractures in Southern Provinces of India. J Oral Heal Community Dent 2017; 11: 5-7.

5. Mesgarzadeh A, Shahamfar M, Azar S, et al. Analysis of the pattern of maxillofacial fractures in north western of Iran: A retrospective study. J Emerg Trauma Shock. Epub ahead of print 2011. DOI: 10.4103/0974-2700.76837.

6. Ramalingam S. Role of maxillofacial trauma scoring systems in determining the economic burden to maxillofacial trauma patients in India. J Int Oral Heal 2015; 7: 38-43.

7. Sand L, Gavelin P, Hirsch J, et al. A retrospective study of patients with mandibular fractures treated at a Swedish University Hospital 1999-2008. Ann Maxillofac Surg. Epub ahead of print 2014. DOI: 10.4103/2231-0746.147119.

8. Rustagi N, Kumar A, Norbu L, et al. Applying Haddon Matrix for Evaluation of Road Crash Victims in Delhi, India. Indian J Surg 2018; 80: 479-487.

9. Boffano P, Kommers SC, Karagozoglu KH, et al. Aetiology of maxillofacial fractures: A review of published studies during the last 30 years. Br J Oral Maxillofac Surg 2014; 52: 901-906.

10. Scherbaum Eidt JM, De Conto F, De Bortoli MM, et al. Associated Injuries in Patients with Maxillofacial Trauma at the Hospital São Vicente de Paulo, Passo Fundo, Brazil. J Oral Maxillofac Res 2013; 4: $1-8$.

11. Gadre KS, Halli R, Joshi S, et al. Incidence and Pattern of CranioMaxillofacial Injuries: A 22 year Retrospective Analysis of Cases Operated at Major Trauma Hospitals/Centres in Pune, India. J Maxillofac Oral Surg 2013; 12: 372-378.

12. Gali R, Devireddy S, Kishore Kumar R, et al. Faciomaxillary fractures in a Semi-urban South Indian Teaching Hospital: A retrospective analysis of 638 cases. Contemp Clin Dent; 6. Epub ahead of print 2015. DOI: 10.4103/0976-237X.169847.

13. Malara P, Malara B, Drugacz J. Characteristics of maxillofacial injuries resulting from road traffic accidents - a 5 year review of the case records from Department of Maxillofacial Surgery in Katowice, Poland. Head face Med 2006; 2: 27.

14. Chalya PL, Mchembe M, Mabula JB, et al. Etiological spectrum, injury characteristics and treatment outcome of maxillofacial injuries in a Tanzanian teaching hospital. J Trauma Manag Outcomes 2011; 5: 7.

15. Farias IPSE, Bernardino ÍDM, Nobrega LM Da, et al. Maxillofacial Trauma, Etiology and Profile of Patients: an Exploratory Study. Acta 
Ortopédica Bras 2017; 25: 258-261.

16. Arabion HR, Tabrizi R, Aliabadi E, et al. A Retrospective Analysis of Maxillofacial Trauma in Shiraz, Iran: a 6-Year- Study of 768 Patients (2004-2010). J Dent 2014; 15: 15-21.

17. Abbas I, Fayyaz M, Shah I, et al. Demographic distribution of maxillofacial fractures in Ayub Teaching Hospital: 7-year review. J Ayub Med Coll Abbottabad 2009; 21: 110-112.

18. Kapoor P, Kalra N. A retrospective analysis of maxillofacial injuries in patients reporting to a tertiary care hospital in East Delhi. Int J Crit Illn Inj Sci 2012; 2: 6-10.

19. Shah A, Nautiyal V, Gupta A, et al. Trends of maxillofacial fractures in the Garhwal Himalayas at Government Medical College, Srinagar, Uttarakhand. Natl J Maxillofac Surg 2016; 7: 80.

20. Béogo R, Dakouré P, Savadogo LB, et al. Associated injuries in patients with facial fractures: a review of 604 patients. Pan Afr Med J 2013; 16: 119 .

21. Obimakinde OS, Ogundipe KO, Rabiu TB, et al. Maxillofacial fractures in a budding teaching hospital: A study of pattern of presentation and care. Pan Afr Med J 2017; 26: 1-9. 